\title{
Optimizing the management of Kindergarten Teachers
}

\author{
Yali Song \\ Shaanxi Xueqian Normal University Xi'an City, Shaanxi Province 710061
}

Keywords: Kindergarten, the management of Kindergarten Teachers

Abstract: The member of an organization is the core of management as well as the construction of kindergarten teachers who is the guarantee of kindergarten. One of the key factors is teaching quality and achieving sustainable development. At present, kindergarten in our province is facing some problems that are severe. The overall construction and management of teaching staff is progressing, but there is still much space to improve. The artcle states that it should take vision as the leading factor and teachers' morality as the soul and ability.

\section{Building for the system of management and human nature management as the two wings in} all aspects of cooperation.

We should constantly optimize the management of teachers. Vision is the common aspiration of an organization member to the development of an organization. The idea of the administration is cohesion of spiritual strength as well as cohesive organization. It takes the powerful role to struggle. In kindergarten, vision leadership is to mobilize through the explicit vision of kindergarten.

\subsection{Encourage and organize preschool teachers to act spontaneously and move towards process of the goal ideal.}

How to guide the kindergarten in the right vision? First, we must be clear the goal of kindergartens which is to describe the development prospects of kindergartens. Use image thinking to make specific depiction. The two is to clarify the concept of education. What kind of spirit and values do we need to nurture children's growth? Thirdly, it is necessary to clarify the relationship between kindergarten vision and teachers' personal growth and value realization. Only in this way can the collective and individual vision be coordinated. Forth, it is to make the goal of early childhood education clear, that is, cultivate what kind of children. In kindergarten, vision guidance is for all teachers' resources and teaching in schools. The overall coordination of resources, management resources needs us to have done a lot of work.

\section{Strengthen the construction of teachers' morality and optimize the management of the soul.}

Preschool teachers should have good professional ethics, which can not only help them effectively, but also deal with various problems in professional practice .It can guide them to all kinds of problems. Educational events make a good judgement of value. 


\subsection{Way to know virtue and value virtue in order to strengthen teacher ethics education}

At first, teachers have the foundation of virtue. They must adhere to the rule of virtue first. The regulations on "professional ethics for teachers and professional standards for kindergarten teachers who are strict with students. It requires that teachers take professional ethics as the first lesson of teaching staff construction. The most important lesson comes from self-learning, collective learning, sharing and other methods.

\subsection{Constantly, the preshool and teachers themselves should improve the level of professional ethics of teachers.}

Teachers should love preschool education and fulfill their teaching that should have the professional ethics. As a teacher, it shold be teaching by virtue that is self-respect and self-discipline.

\section{To respect children's personality, love, sense of responsibility and patience in order to make children healthy.}

The enlightenment and guide maintain the love of children and career. Teachers need to have the ability to control your emotions that master the skills of getting along with others who is communicating with others. We should properly handle the relationship between teachers and leaders, even for interpersonal relationships between parents. Finally, we should protect virtue and advocate morality. To strengthen the construction of teachers' morality, we must start from kindergarten. At the organizational level, we should safeguard teachers' ethics, as well as advocating teachers' ethics and creating a good atmosphere. The manager is in the management process which attaches importance to training teachers whose lofty professional consciousness, perseverance and open-minded.

It makes every teachers'ersonality noble .All of them have a positive impact on children's growth. Teachers should make commendation regular so as to promote virtue and promote righteousness. Those who violate professional ethics should be punished in time to eliminate bad habits and suppress bad habits.

\subsection{Strengthen capacity building and optimize technology management}

The construction of teaching staff should be based on ability that it is improving preschool teachers' education and teaching. Conservation ability is a long-term work in kindergartens, and is also the basis for optimizing management.

\subsection{Strengthen basic capabilities.}

A qualified preschool teacher should have basic skills. Professional ability, such as curriculum design ability, activity organizing ability should observe the analysis of ability. This is the basis for kindergarten teachers to engage in education and teaching. Preschool teachers should seriously study the guidelines for kindergarten education. There is a guide to learning and development for children to truly understand their core ideas which is to enhance their education to internalize ideas of educational behaviors in order to develop self-education behaviors and habits that are to better serve the teaching practice. 


\subsection{Develop key capabilities. Teachers of every age group have their own.}

In the most recent development area, for example, the young teachers' Development Zone is to do regular education. The key development area for teachers is to break through the bottleneck as to create their own teaching characteristics. Kindergartens should carefully analyze that each teacher's characteristics join them in order to identify their respective areas of proximal development.

\subsection{Strengthen professional training.}

Kindergartens should establish various forms of nursing education industry development, which is training mechanism, to build a platform for the professional development of teaching staff who is to promote teaching. The overall development of staff has the formulation of professional plans at all levels about clear objectives. Measures are regular for inspections and summaries. Teachers should be organized to take an active part in continuing education which takes out visits to study. It is pleased to come in to teach experience as to listen to lectures for learning to improve to open courses promote progress which is symposium, common development and other business training methods. It promotes teachers' language, communication, organization, observation, conservation that is scientific research, innovation and other teaching.

\subsection{Strengthen supervision and inspection.}

Kindergarten teachers should be pushed to attend classes. And "half day activities is comprehensive inspection that is teaching supervisor to follow the supervision referring to the process. The standards is to conduct a survey on the standardized implementation of teachers' daily activities. The blind spots and busy points in the process of organizing half day activities. Manager should form children's performance to teachers' ability to emotion and organization which has implementation strategies from a variety of angles. We should examine the strengths and weaknesses of teachers in the half day activities which teach them in time. Teachers communicate with each other to help teachers clarify the problems in order to put forward suggestions for improvement as well as tracking supervision. For the class ,it is better implementation with method of field guidance that is adopted to solve existing problems In order to adopt class ,the on-site instructions cope with larger problems in implementation It posts activity analysis of guidance, which phased track and help teachers change ideas. It is learning methods and experience.

\section{Reflect humanization and optimize management in the system.}

We should optimize the system that is democratic management. It builds equal competition and performance and priority that is rewarded for diligence. Other ways are competitive while it is binding management mechanisms. Enhancing the sense of responsibility is vital to teachers. The core of kindergarten development is not only education, but also effective. There is twenty percent of the hundred workers who are on the right side to work ten. The technological innovation of science lies in building up the strength of the team that is improving the quality of teaching method for institutional innovation. The member of an organization is the core of management and the construction of kindergarten teachers who are the guarantee of kindergarten.

One of the key factors is teaching quality that is achieving sustainable development. At present, kindergarten in our province is facing the problems.The overall construction of teaching staff is progressing, but there is still much space to improve. The author believes that we should take vision as the leading factor that teachers' morality is key points for the soul and ability.

Managers should be good at grasping the key issues and keen insight into phenomena. The crux 
of the problem is in the process of institutional revision and innovation. We should fully listen to public opinion. Let's talk about the system. from the needs and the benefits, the garden finds the defects of the current system that adjusts relationship that comes from teachers. The system generated by teachers is highly acceptable and highly operational. In fact, it is easier for teachers to consciously accept and obey, which is conducive to the implementation of the system to improve work efficiency. System management can make the teaching team develop good environment quicklyand steadily improving the quality of work, so that kindergartens really go to the track of healthy development. With the experience of participation in management, teachers will really feel that they are the masters of kindergartens.

People will consciously safeguard the collective interests of the kindergarten and do it more consciously. The tasks, which they undertake, achieve the management objectives of kindergartens. On the other hand, we should use humanized management as a complement to institutional management. With the development of organizations, there will be limitations in simple institutional management. Because of the system. Management is the use of coercive means, relying on external force that is to restrain human behavior. The system is rigid. It is concerned with people's emotional and internal needs. Obviously, Kindergarten is no exception, especially for most employees. Rules and regulations that is good for kindergartens .It is good atmosphere to have come into being.

Developing the core competitiveness of the organization has become an inevitable choice for the survival and development of colleges and universities. Core competition of universities is the accumulation system formed by the unique knowledge of the school, and its deep connotation includes excellent culture and advanced system are concentrated on the ability of talents and academic research. And the ability to serve the society, all of them are based on the high level of human resources. At present, the problems in the development and management of human resources in Chinese universities are quite serious. In order to improve the quality of education and the efficiency of running schools, it is necessary to improve the quality and efficiency of running colleges and universities. The overall quality of human resources in universities depends largely on human resources which only adhere to the "people-oriented" concept of human resources development through human resources. The management system and operation mechanism should be innovating, and a reasonable and effective plan for human resource development and management should be worked out. In order to meet the requirements of scientific whose standardized and democratized human resources development and management in universities and colleges. Finally, It is significant to cultivate and enhance the core competitiveness of the school.

Management is not enough for humanistic management to need supplement. Garden leaders should pay attention to emotion. Communication, understanding and respect for the needs of workers in order to orcreate a harmonious atmosphere that teachers are in the good mental work. Our achievements for every teacher must give full recognition. Sometimes, a approving smile is affirmation. We must give full recognition. Words and a proper reward can play a great role.

In short, kindergartens should strive to build a virtuous teacher with excellent professional skills.

Reasonable, passionate and innovative spirit can adapt to the needs of curriculum reform.

We should actively promote the professionalization of teaching staff that optimizes the structure of teaching staff ultimately .It achieves the ultimate goal for the healthy and sustainable development of kindergartens.

\section{References}

[1] Xu Xiaoli, evaluation of early childhood development: the process of attention is focused on the development of [J]. Preschool education.

[2] Yu Fang. Requirements, characteristics and value of implementing differentiated evaluation for children. Tian [J]. Preschool 
[3] Zhang Jing. Multivariate evaluation to promote the individual development of children [J]. Journal of Kaifeng Institute of Education

[4] Ning Yanling. Training preschool education majors in kindergarten environment creation in practice. Ability [door]. Journal of Mudanjiang University, 2014, 10:182-184

[5] Ning Yanling. Strategies for developing preschool education students' environmental creation ability in kindergartens [Journal of Qiqihar Teachers College, 2013, 06:33-34]

[6] Yang Yuhong, the training of preschool education majors, the creation of theme environment in kindergartens 